\title{
PENGARUH RASIO LIQUIDITAS TERHADAP RASIO PROFITABILITAS PADA PT. ADIRA DINAMIKA MULTIFINANCE, TBK DI JAKARTA PERIODE 2011-2020
}

\author{
Siti Nurcahayati \\ Universitas Pamulang, Tangerang Selatan, Banten, Indonesia \\ dosen02356@unpam.ac.id
}

\begin{abstract}
Abstrak
Penelitian ini bertujuan untuk mengetahui pengaruh Current Ratio terhadap Return On Asset pada PT. Adira Dinamika Multifinance, Tbk di Jakarta. Metode yang digunakan adalah explanatory research. Teknik analisis menggunakan analisis statistik dengan pengujian regresi, korelasi, determinasi dan uji hipotesis. Hasil penelitian ini variabel Current Ratio diperoleh nilai rata-rata sebesar 127,57\%. Variabel Return On Asset diperoleh nilai rata-rata $72,36 \%$. Current Ratio berpengaruh positif dan signifikan terhadap Return On Asset dengan nilai persamaan regresi $Y=24,643+0,374 X$, dan nilai koefisien korelasi 0,878 atau memiliki tingkat hubungan yang kuat dengan nilai determinasi sebesar $77,1 \%$. Uji hipotesis diperoleh signifikansi 0,001<0,05.
\end{abstract}

Kata Kunci: Current Ratio, Return On Asset.

This study aims to determine the effect of the Current Ratio on Return On Assets at PT. Adira Dinamika Multifinance, Tbk in Jakarta. The method used is explanatory research. The analysis technique uses statistical analysis with regression, correlation, determination and hypothesis testing. The results of this research variable Current Ratio obtained an average value of $127.57 \%$. The Return On Assets variable obtained an average value of $72.36 \%$. Current Ratio has a positive and significant effect on Return On Assets with a regression equation value of $Y=24,643+0.374 X$, and a correlation coefficient value of 0.878 or has a strong relationship with a determination value of $77.1 \%$. Hypothesis testing obtained a significance of $0.001<0.05$.

Keywords: Current Ratio, Return On Assets. 


\section{PENDAHULUAN}

Masalah keuangan merupakan hal yang sangat mempengaruhi perusahaan dalam perkembangan bisnis di semua perusahaan. Tujuan manajemen keuangan dalam sebuah perusahaan adalah untuk mendapatkan laba sesuai dengan yang ditetapkan dan sebagai pengambilan keputusan dimasa depan. Namun berhasil tidaknya perusahaan dalam mencari keuntungan dan mempertahankan perusahaannya tergantung pada manajemen keuangan.

Pelaku usaha harus mencermati dan menganalisis kinerja usahanya agar dapet bertahan, salah satu cara yang dapat dilakukan adalah dengan melakukan analisis kinerja dari sisi keuangan terhadap laporan keuangan. Penilaian usaha dapat dilakukan dengan menganalisis dua aspek,yaitu kinerja finansial dan kinerja non finansial. Kinerja finansial dapat dilihat melalui data data laporan keungan, sedangkan kinerja non-finansial dapat dilihat dari segi pelayanan, pemasaran, teknologi, maupun manajemennya.

Menurut Irham Fahmi (2015:239) kinerja keungan adalah suatu analisis yang dilakukan untuk melihat sejauh mana suatu perusahaan telah melaksanakan dengan menggunakan aturan-aturan pelaksanaan keuangan secara baik dan benar. Salah satu metode yang dapat digunakan untuk mengukur dan menilai kinerja keungan suatu perusahaan adalah melalui analisis rasio keuangan. Caranya adalah dengan membandingkan angka-angka yang ada dalam laporan keuangan (Kasmir, 2012:104). Analisis rasio merupakan analisis yang digunakan untuk mengetahui hubungan pos-pos yang ada dalam satu laporan keuangan atau pos-pos antara laporan keuangan neraca dan laporan laba rugi. (Kasmir, 2012:72). Analisis rasio keuangan juga merupakan suatu cara analisa dengan menggunakan perhitunganperhitungan perbandingan atas data-data keuangan yang ada dalam neraca, laporan arus kas maupun laba rugi sehingga didapat angka rasio masing-masing data keuangannya.
Analisis rasio keuangan merupakan analisis yang paling sering dibandingkan dengan analisis keuangan lainnya (Hery, 2015:161). Dari beberapa analisis rasio keuangan yang dapat digunakan dalam menilai kinerja keuangan diantaranya adalah analisis rasio likuiditas dan rasio profitabilitas. Menurut Kasmir (2012:110). Rasio likuiditas merupakan yang menunjukkan kamampuan perusahaan untuk membayar utang-utang (kewajiban) jangka pendeknya yang jatuh tempo, atau rasio untuk mengetahui kemampuan perusahaan dalam membiayai dan memenuhi kewajiban (utang) pada saat ditagih. Menurut Munawir (2014:86), rasio profitabilitas merupakan rasio untuk mengukur profit yang diperoleh dari modal yang digunakan untuk operasi tersebut atau mengukur kemampuan perusahaan untuk memperoleh keuntungan.

Mengingat pentingnya analisis keuangan untuk menilai kinerja keuangan pada suatu perusahaan sehingga sangat berguna bagi pihak manajemen terlebih bagi pimpinan perusahaan untuk terus mengetahui kondisi keuangan perusahaan termasuk peningkatan laba operasional dan pos-pos keuangan lainnya. Dalam hal ini dapat dilihat bahwa terjadi ketidaksamaan antara likuiditas dengan profitabilitas. Tingkat likuiditas yang tidak sejalan dengan perkembangan profitabilitas. Kenyataan tersebut terkadang sering dijumpai tidak selaras dengan teori yang ada, dimana secara teori apabila perusahaan memiliki tigkat modal kerja yang tinggi maka tingkat profitabilitasnya juga akan tinggi. Begitupun hubungannnya dengan tingkat likuiditas yang diperoleh perusahaan uang memiliki pengaruh terhadap tingkat profitabilitas. Oleh karena itu, perlu penelitian untuk mengetahui pemgaruh tingkat likuiditas yang diperoleh dan ditinjau dari tingkat profitabilitas yang dicapai perusahaannya.

Berdasarkan latar belakang yang telah dikemukakan diatas, maka peneliti tertarik untuk melakukan penelitian tentang "Pengaruh Rasio Likuiditas Terhadap Rasio Profitabilitas Pada PT. Adira Dinamika 
Multifinance, Tbk di Jakarta".

\section{METODE PENELITIAN}

\section{Populasi}

Populasi dalam penelitian ini laporan keuangan PT. Adira Dinamika Multifinance, Tbk di Jakarta selama 10 tahun

\section{Sampel}

Teknik pengambilan sampling dalam penelitian ini adalah samplel jenuh, dimana semua anggota populasi dijadikan sebagai sampel. Dengan demikian sampel dalam penelitian ini laporan keuangan PT. Adira Dinamika Multifinance, Tbk di Jakarta selama 10 tahun.

\section{Jenis Penelitian}

Jenis penelitian yang dipakai adalah kuantitatif, dimana tujuannya

Tabel 1. Hasil Analisis Descriptive Statistics

Descriptive Statistics

\begin{tabular}{lr|r|r|r|r} 
& $\mathrm{N}$ & Minimum & Maximum & Mean & Std. Deviation \\
\hline CR & 10 & 97.85 & 195.43 & 127.5740 & 35.45722 \\
\hline ROA & 10 & 50.18 & 99.22 & 72.3600 & 15.10425 \\
\hline Valid N (listwise) & 10 & & & & \\
\hline
\end{tabular}

Current Ratio diperoleh nilai minimum sebesar $97,85 \%$ dan nilai maximum $195,43 \%$ dengan rata-rata sebesar $127,57 \%$ dengan standar deviasi $35,45 \%$.

Sedangkan nilai Return On Asset diperoleh nilai minimum sebesar 50,18\% dan nilai maximum $99,22 \%$ dengan ratarata sebesar $72,36 \%$ dengan standar deviasi $15,10 \%$.

\section{Analisis Kuantitatif}

Pada analisis ini dimaksudkan untuk mengetahui pengaruh variabel independen terhadap variabel dependen. Adapun hasil pengujian sebagai berikut:

a. Analisis Regresi Linier Sederhana

Uji regresi ini dimaksudkan untuk mengetahui perubahan variabel dependen jika variabel independen mengalami perubahan. Adapun hasil pengujiannya sebagai berikut:

Tabel 2. Hasil Pengujian Regresi Linier Sederhana

\section{Coefficients $^{\mathrm{a}}$}

Unstandardized Coefficients Standardized Coefficients

\begin{tabular}{lr|r|r|r|r} 
Model & B & \multicolumn{1}{|c|}{ Std. Error } & Beta & $\mathrm{t}$ & Sig. \\
\hline 1 (Constant) & 24.643 & 9.510 & & 2.591 & .032 \\
\hline CR & .374 & .072 & .878 & 5.189 & .001 \\
\hline
\end{tabular}

a. Dependent Variable: ROA

Berdasarkan hasil pengujian pada tabel di atas, diperoleh persamaan regresi $\mathrm{Y}=24,643+$
0,374X. Dari persamaan tersebut dijelaskan sebagai berikut:

1) Konstanta sebesar 24,643 diartikan 
jika Current Ratio tidak ada, maka telah terdapat nilai Return On Asset sebesar 24,643 point.

2) Koefisien regresi Current Ratio sebesar 0,374, angka ini positif artinya setiap ada peningkatan Current Ratio sebesar 0,374 point maka Return On Asset juga akan mengalami peningkatan sebesar 0,374 point.

\section{b. Analisis Koefisien Korelasi}

Analisis koefisien korelasi dimaksudkan untuk mengetahui tingkat kekuatan hubungan dari variabel independen terhadap variabel dependen. Adapun hasil pengujian sebagai berikut:

Tabel 3. Hasil Pengujian Koefisien Korelasi Current Ratio Terhadap Return On Asset.

\section{Correlations $^{b}$}

\begin{tabular}{llr|r} 
& & CR & \multicolumn{1}{c}{ ROA } \\
\hline CR & Pearson Correlation & 1 & $.878^{* *}$ \\
\cline { 2 - 4 } & Sig. (2-tailed) & & .001 \\
\hline ROA & Pearson Correlation & $.878^{* *}$ & 1 \\
\cline { 2 - 4 } & Sig. (2-tailed) & .001 & \\
\hline \multirow{2}{*}{ **. Correlation is significant at the 0.01 level (2-tailed). } \\
b. Listwise N=10
\end{tabular}

Berdasarkan hasil pengujian diperoleh nilai korelasi sebesar 0,878 artinya Current Ratio memiliki hubungan yang sangat kuat terhadap Return On Asset.

\section{c. Analisis Koefisien Determinasi}

Analisis koefisien determinasi dimaksudkan untuk mengetahui besarnya persentase pengaruh dari variabel independen terhadap variabel dependen. Adapun hasil pengujian sebagai berikut:

Tabel 4. Hasil Pengujian Koefisien Determinasi Current Ratio Terhadap Return On

Asset.

Model Summary

\begin{tabular}{lr|r|r|r} 
Model & R & R Square & Adjusted R Square & Std. Error of the Estimate \\
\hline 1 & $.878^{\mathrm{a}}$ & .771 & .742 & 7.66706 \\
\hline
\end{tabular}

a. Predictors: (Constant), CR

Berdasarkan hasil pengujian diperoleh nilai determinasi sebesar 0,771 artinya Current Ratio memiliki kontribusi pengaruh sebesar 77,1\% terhadap Return On Asset, sedangkan sisanya sebesar $22,9 \%$ dipengaruhi faktor lain.

\section{d. Uji Hipotesis}

Pengujian hipotesis dengan uji t digunakan untuk mengetahui hipotesis mana yang diterima.

Rumusan hipotesis: Terdapat pengaruh yang signifikan Current Ratio terhadap Return On Asset.

Tabel 5. Hasil Uji Hipotesis Current Ratio Terhadap Return On Asset.

\section{Coefficients ${ }^{\mathrm{a}}$}

Unstandardized Coefficients Standardized Coefficients

\begin{tabular}{lr|r|r|r|r} 
Model & $\mathrm{B}$ & Std. Error & Beta & $\mathrm{t}$ & Sig. \\
\hline 1 (Constant) & 24.643 & 9.510 & & 2.591 & .032 \\
\hline CR & .374 & .072 & .878 & 5.189 & .001 \\
\hline
\end{tabular}

a. Dependent Variable: ROA

Berdasarkan hasil pengujian pada tabel di atas, diperoleh nilai $\mathrm{t}$ hitung $>\mathrm{t}$ tabel atau $(5,189>2.306)$, hal tersebut juha diperkuat dengan signifikansi 0,001 < 0,05, dengan demikian hipotesis yang diajukan 
bahwa terdapat pengaruh yang signifikan Current Ratio terhadap Return On Asset diterima.

\section{PEMBAHASAN HASIL PENELITIAN}

\section{Kondisi Nilai Variabel Current Ratio}

Berdasarkan data empiris dan analisis data, variabel Current Ratio diperoleh nilai rata-rata per tahun sebesar $127,57 \%$.

\section{Kondisi Nilai Variabel Return On Asset}

Berdasarkan data empiris dan analisis data, variabel Return On Asset diperoleh nilai rata-rata per tahun sebesar 39,06\%.

\section{Pengaruh Current Ratio Terhadap Return On Asset}

Current Ratio berpengaruh signifikan terhadap Return On Asset dengan persamaan regresi $Y=24,643+$ $0,374 \mathrm{X}$, nilai korelasi sebesar 0,878 atau memiliki hubungan yang sangat kuat dengan kontribusi pengaruh sebesar $77,1 \%$, sedangkan sisanya sebesar $22,9 \%$ dipengaruhi faktor lain. Pengujian hipotesis diperoleh nilai $\mathrm{t}$ hitung $>\mathrm{t}$ tabel atau $(5,189>2.306)$. Dengan demikian hipotesis yang diajukan bahwa terdapat berpengaruh signifikan Current Ratio terhadap Return On Asset diterima.

\section{KESIMPULAN DAN SARAN}

Kesimpulan

a. Kondisi variabel Current Ratio berdasar pada periode laporan keuangan 10 tahun diperoleh Current Ratio rata-rata sebesar $127,57 \%$.

b. Kondisi variabel Return On Asset berdasar pada periode laporan keuangan 10 tahun diperoleh Current Ratio ratarata sebesar 39,06\%.

c. Current Ratio berpengaruh signifikan terhadap Return On Asset dengan persamaan regresi $\mathrm{Y}=24,643+0,374 \mathrm{X}$, nilai korelasi sebesar 0,878 atau sangat kuat dan kontribusi pengaruh sebesar $77,1 \%$ sedangkan sisanya sebesar $22,9 \%$ dipengaruhi faktor lain. Uji hipotesis diperoleh nilai $\mathrm{t}$ hitung $>\mathrm{t}$ tabel atau
$(5,189>2.306)$

\section{Saran}

Berdasarkan hasil penelitian yang sudah disimpulkan, maka penulis memberikan saran sebagai berikut:

a. Perusahaan harus mempertahankan posisi Current Ratio nya, karena dengan Current Ratio yang baik menunjukkan perusahaan dapat memenuhi kewajiban jangka pendeknya, tetapi Current Ratio yang terlalu tinggi pula dapat dikatakan tidak baik karena menandakan kelebihan uang kas atau aktiva lancar yang dibutuhkan

b. Perusahaan diharapkan dapat meningkatkan profitabiltas dengan cara melakukan survey lapangan terhadap para konsumen mengenai apa yang konsumen perlakukan, hal ini dimaksud untuk meningkatkan penjualan lebih baik lagi.

\section{DAFTAR PUSTAKA}

Agus Harjito \& Martono, (2015) “Manajemen Keuangan" Yogyakarta: Penerbit Ekonisia.

Agus Sartono. (2016). "Manajemen Keuangan Toeri dan Aplikasi", Edisi keempat, Yogyakarta: Penerbit BPFE.

Algifari. (2015). “Analisis Regresi untuk Bisnis dan Ekonomi". Yogyakarta: BPFE.

Arikunto, Suharsimi (2014). "Prosedur Penelitian Suatu Pendekatan Praktek". Jakarta: Rineka Cipta.

Bambang Riyanto, (2011). "Dasar-dasar Pembelanjaan Perusahaan". Edisi ke empat, Yogyakarta: BPFE.

Fahmi, Irham (2012), "Pengantar Manajemen Keuangan" Cetakan pertama. Bandung: Penerbit Alfabeta.

Haque, M. G., Nurjaya, N., Affandi, A., Erlangga, H., \& Sunarsi, D. (2021). Micro Financial Sharia Non-bank Strategic Analysis: a Study at BMT Beringharjo, Yogyakarta. Budapest International Research and Critics Institute (BIRCI-Journal): Humanities and Social Sciences, 4(2), 1677-1686. 
Imam Ghozali (2017). "Aplikasi Analisis Multivariate Dengan Program SPSS". Edisi Kelima. Semarang: Badan Penerbit Undip.

Kasmir. (2012) "Pengantar Manajemen Keuangan", Edisi Pertama, Cetakan kedua, Jakarta: Prenada Media.

Lutfi, A. M., Erlangga, H., Nurjaya, N., Priadana, S., \& Dwiwarman, D. A. (2021). Pengaruh Capital Adequacy Ratio Dan Bopo Ratio Terhadap Return On Asset Pada Pt. Bank Muamalat Indonesia, Tbk Periode 2010-2019. Jurnal Ekonomi Efektif, 3(3).

Martono dan Agus Harjito, (2011). "Manajemen Keuangan", Jakarta: Penerbit Ekonisia.

Munawir (2010), "Analisis Laporan Keuangan", Edisi Ke Empat, Yogyakarta: Penerbit Liberty.

Najibullah, et al. (2021). Pengaruh non Performing Financing dan Financing to Deposit Ratio terhadap Pembiayaan pada Bank DKI Syariah. Jurnal Neraca Peradaban. Volume 1. Issue1. Pages 48-5

Muslimat, A., Muhsin, H., Wahid, H. A., Yulistiana, I., Sunarsi, D., Dewi, K., ... \& Ilham, D. (2021). Develop Technology Based Multimedia For Indonesian Teachers. Journal of Contemporary Issues in Business and Government, 27(1), 1871-1882.

Purwanti, Y. (2021). The Influence Of Digital Marketing \& Innovasion On The School Performance. Turkish Journal of Computer and Mathematics Education (TURCOMAT), 12(7), 118127.

Muslimat, A. (2021). Masa Depan Kampus Merdeka \& Merdeka Belajar: Sebuah
Bunga Rampai Dosen. Bintang Visitama Publisher.

Nurjaya, N., Affandi, A., Ilham, D., Jasmani, J., \& Sunarsi, D. (2021). Pengaruh Kompetensi Sumber Daya Manusia Dan Kemampuan Pemanfaatan Teknologi Terhadap Kinerja Aparatur Desa Pada Kantor Kepala Desa Di Kabupaten Gunungkidul, Yogyakarta. JENIUS (Jurnal Ilmiah Manajemen Sumber Daya Manusia), 4(3), 332-346.

Nurjaya, et al (2021). Pengaruh Liquiditas dan Profitabilitas terhadap Return Saham: Studi Empiris Pada Perusahaan Real Estate Dan Property Yang Terdaftar Di Bursa Efek Indonesia Tahun 2017-2019. Jurnal Tadbir Peradaban Volume 1. Issue.1. Pages 60-68.

Pujiati, H., Sunarsi, D., Affandi, A., \& Anggraeni, N. (2021). Effect of ISO 9001: 2015 Quality Management Implementation in Education on School Performance. Journal of Contemporary Issues in Business and Government, 27(1), 1848-1855.

Salam, A., Hikmat, I., Haquei, F., \& Badariah, E. (2021). The Influence of Share Ownership, Funding Decisions, Csr and Financial Performance of Food Industry. Annals of the Romanian Society for Cell Biology, 12698-12710.

Sawir, (2003). “Analisis Kinerja Keuangan dan Perencanaan Keuangan Perusahaan", Cetakan ketiga, Jakarta: Penerbit PT. Gramedia Pustaka Utama.

Sugiyono (2017), “Metode Penelitian Administrasi : dilengkapi dengan Metode R\& D". Bandung: Alfabeta. 